\title{
Spacing and Age Effects on Biomass Production in Red Pine Plantations
}

by

\author{
I.S. Alemdag and W.M. Stiell1
}

\begin{abstract}
Data and wood samples were collected from 155 trees in 16 high-survival, unthinned plantations of red pine (Pinus resinosa Ait.) near Chalk River, Ontario, aged 27 to 54 years, with initial spacings of from $1.52 \times$ $1.52 \mathrm{~m}$ to $4.27 \times 4.27 \mathrm{~m}$. Following standard weighing and drying procedures, ovendry mass values of the whole tree and or their individual components were calculated, and regressions developed to relate mass values to stem dimensions of diameter breast height (d) and total height (h), and to determine what effects the initial spacing and stand age had on those relations. Single-tree equations based simply on $d$ and $h$ gave satisfactory mass estimates only for the whole tree and for the component stem bark. For other components the addition of spacing and age showed successive improvements in the estimates over those provided by $\mathrm{d}^{2} \mathrm{~h}$ alone.
\end{abstract}

\section{Résumé}

On a récolté des données ainsi que des échantillons de bois sur 155 arbres, dans seize plantations, non éclaircies et à taux élevé de survie, de pin rouge (Pinus resinosa Ait.) de la région de Chalk River en Ontario, âgées de 27 à 54 ans et dont l'espacement initial variait de $1,52 \mathrm{~m}$ sur 1.52 à $4,27 \mathrm{~m}$ sur 4,27 . À l'aide de méhodes normalisées de pesage et de séchage, on a calculé la masse anhydre des arbres entiers et de chacun de leurs constituants et on a élaboré des régressions afin de corréler la masse au diamètre à hauteur d'homme (d) et à la hauteur totale (h) et de déterminer les effets de l'espacement initial et de l'âge du peuplement sur ces corrélations. On a obtenu des estimations satisfaisantes de la masse de l'arbre entier et de celle de l'écorce de la tige à l'aide d'équations établies pour un seul ar. bre à partir simplement de $\mathrm{d}$ et de $\mathrm{h}$. Quant aux autres constituants, l'espacement et l'âge ont permis d'en améliorer successivement l'estimation, comparativement à celle que procurait $\mathrm{d}^{2} \mathrm{~h}$ seulement.

\section{Introduction}

The powerful influence of planted spacing on development of the individual tree, and on volume production per hectare, has been demonstrated for red pine (Pinus resinosa Ait.) in several studies at the Petawawa National Forestry Institute, Chalk River, Ontario, e.g. Berry (1977), Stiell and Berry (1977). The possibility of managing the species for biomass production, or its partial utilization for that purpose, prompted the investigation of spacing effects on red pine mass (weight) production described here.

This study was carried out in plantations at or near the Institute, to relate the ovendry mass (OM) of the aboveground

\footnotetext{
${ }^{1}$ Petawawa National Forestry Institute, Chalk River, Ontario.
}

portion of the tree to the stem dimensions of diameter breast height (dbh) and height, and to determine what effects the initial spacing and stand age had on the relations found. ${ }^{2}$ Appropriate equations were to be developed for estimating $\mathrm{OM}$ from the independent variables both for the tree in toto and separately for the following components: stem wood, stem bark, branches and twigs plus needles. Several investigations of red pine plantation biomass have been reported that deal at least in part with the effects of spacing (Brown 1963, Heiberg, Leyton and Loewenstein 1959, Maeglin 1967, Singer and Hutnik 1966), or of age (Frederick and Coffman 1978, Hannah 1969), but no comprehensive approach to the combined effects on OM of tree components was found.

\section{Methods and Materials}

\section{Plantations}

Data and wood samples were collected from sixteen highsurvival, unthinned plantations growing on old field sites. Soils included windblown and waterlaid fine and medium sands, some interbanded; sandy loam over coarse and gravelly sands; lake-laid medium sand with silt and clay bands below the weathered profile; and moulded tills overlying bedrock at variable depths.

Stand ages ranged from 27 to 54 years from planting, and initial spacings from $1.52 \times 1.52 \mathrm{~m}$ to $4.27 \times 4.27 \mathrm{~m}(5 \times 5 \mathrm{ft}$ to $14 \times 14 \mathrm{ft}$ ). Hereinafter square spacings will be referred to by one dimension only, e.g. $1.52 \mathrm{~m}$. Variation in individual tree size was from 6.5 to $36.2 \mathrm{~cm}$ in $\mathrm{dbh}$, and 9.2 to $25.2 \mathrm{~m}$ in height.

\section{Sampling and Measurement}

In each plantation measurements were taken on one or more existing permanent sample plots to provide information on numbers of trees per hectare and their diameter and height distribution. Using the diameter range as a guide, from 7 to 11 trees were felled and measured in the im. mediate vicinity of the plot. The sampling distribution by numbers of plots and trees in each age and spacing category is shown in Table 1.

Field and laboratory procedures were those described by Alemdag (1980). Briefly, dbh (ob) and crown width were obtained for each standing tree. It was then felled and height to the live crown and total height ( $h$ ) were measured. Diameter (ob) was taken with a tape at ground level, stump height, 0.8 $\mathrm{m}$ and at 2-m intervals (from ground level) up the stem. Bark thickness was measured at each of those points with a bark gauge. Branches were cut off flush with stem and sorted into dead and living, and the latter into three size-classes of which the smallest comprised the fine twigs with attached needles. All branch categories were weighed green and

\footnotetext{
${ }^{2} \mathrm{Dbh}$ and height were chosen as being standard measurements taken for volume estima. tion, and the only ones likely to be collected in a routine inventory. Plantation age is nearly always known, and planted spacing is readily determined as described later.
} 
Table 1. Sampling distribution by plantation age and spacing.

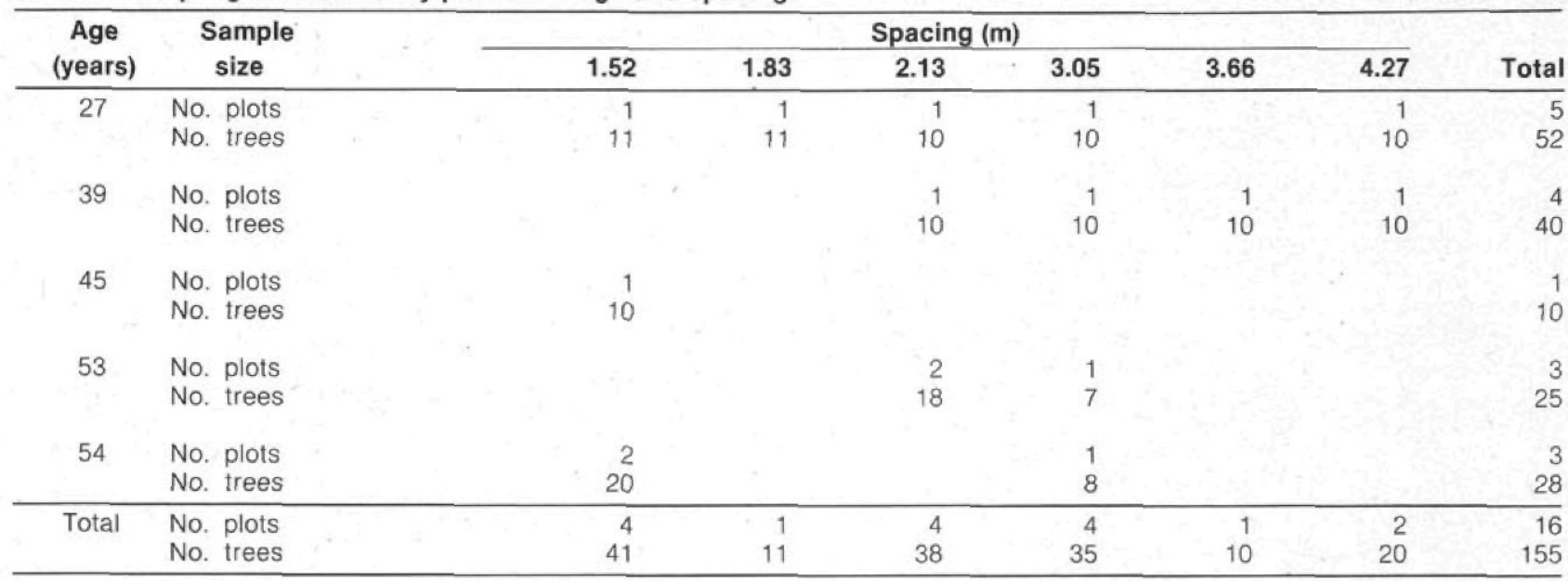

\begin{tabular}{|c|c|c|c|c|c|c|c|}
\hline Component & Model & $b_{0}$ & $b_{1}$ & $b_{2}$ & $b_{3}$ & $\mathbf{R}^{2}$ & SEE \% \\
\hline Stem wood & $\begin{array}{l}(1) \\
(2) \\
(3)\end{array}$ & $\begin{array}{r}5.708 \\
13.545 \\
-4.638\end{array}$ & $\begin{array}{l}0.011968 \\
0.012844 \\
0.012271\end{array}$ & $\begin{array}{l}-22107 \\
-16849\end{array}$ & 0.48819 & $\begin{array}{l}0.956 \\
0.976 \\
0.979\end{array}$ & $\begin{array}{r}13.8 \\
10.3 \\
9.6\end{array}$ \\
\hline Stem bark & $\begin{array}{l}(1) \\
(2) \\
(3)\end{array}$ & $\begin{array}{r}1.923 \\
2.020 \\
-0.021\end{array}$ & $\begin{array}{l}0.001021 \\
0.001032 \\
0.000968\end{array}$ & $\begin{array}{r}-274 \\
316\end{array}$ & 0.05479 & $\begin{array}{l}0.948 \\
0.949 \\
0.954\end{array}$ & $\begin{array}{l}13.0 \\
13.0 \\
12.4\end{array}$ \\
\hline Live branches & $\begin{array}{l}(1) \\
(2) \\
(3)\end{array}$ & $\begin{array}{r}-0.127 \\
-5.408 \\
4.345\end{array}$ & $\begin{array}{l}0.001718 \\
0.001127 \\
0.001435\end{array}$ & $\begin{array}{l}14898 \\
12078\end{array}$ & -0.26185 & $\begin{array}{l}0.558 \\
0.815 \\
0.839\end{array}$ & $\begin{array}{l}60.4 \\
39.2 \\
36.6\end{array}$ \\
\hline Twigs + needles & $\begin{array}{l}(1) \\
(2) \\
(3)\end{array}$ & $\begin{array}{r}3.090 \\
-1.077 \\
10.471\end{array}$ & $\begin{array}{l}0.001114 \\
0.000648 \\
0.001012\end{array}$ & $\begin{array}{r}11754 \\
8415\end{array}$ & -0.31004 & $\begin{array}{l}0.456 \\
0.767 \\
0.834\end{array}$ & $\begin{array}{l}56.6 \\
37.2 \\
31.5\end{array}$ \\
\hline Whole Tree & $\begin{array}{l}(1) \\
(2) \\
(3)\end{array}$ & $\begin{array}{r}10.594 \\
9.080 \\
10.157\end{array}$ & $\begin{array}{l}0.015821 \\
0.015651 \\
0.015686\end{array}$ & $\begin{array}{l}4271 \\
3960\end{array}$ & -0.02891 & $\begin{array}{l}0.976 \\
0.977 \\
0.977\end{array}$ & $\begin{array}{l}9.8 \\
9.7 \\
9.7\end{array}$ \\
\hline (Dead branches) & $\begin{array}{l}(1) \\
(2) \\
(3)\end{array}$ & $\begin{array}{r}2.804 \\
-1.258 \\
6.674\end{array}$ & $\begin{array}{l}0.000636 \\
0.000181 \\
0.009431\end{array}$ & $\begin{array}{r}11458 \\
9164\end{array}$ & -0.21295 & $\begin{array}{l}0.218 \\
0.653 \\
0.700\end{array}$ & $\begin{array}{l}86.2 \\
57.6 \\
53.8\end{array}$ \\
\hline
\end{tabular}

\begin{tabular}{|c|c|c|c|c|c|c|c|c|c|}
\hline \multirow[b]{2}{*}{$\begin{array}{l}\text { Spacing } \\
\text { (m) }\end{array}$} & \multirow[b]{2}{*}{ Model } & & & \multicolumn{6}{|c|}{ Ovendry mass per hectare } \\
\hline & & & & $\begin{array}{l}\text { Stem } \\
\text { wood }\end{array}$ & $\begin{array}{r}\text { Stem } \\
\text { bark }\end{array}$ & $\begin{array}{c}\text { Live } \\
\text { branches }\end{array}$ & $\begin{array}{c}\text { Twigs + } \\
\text { needles }\end{array}$ & $\begin{array}{c}\text { Total } \\
\text { biomass }\end{array}$ & $\begin{array}{c}\text { Dead } \\
\text { branches }\end{array}$ \\
\hline \multirow[t]{3}{*}{1.52} & $\begin{array}{l}\text { (1) } \\
\text { Diff. from (3) }\end{array}$ & $\mathrm{Kg}$ & $\cdot$ & $\begin{array}{l}190338 \\
-22167\end{array}$ & $\begin{array}{r}20068 \\
-451\end{array}$ & $\begin{array}{r}24799 \\
+14701\end{array}$ & $\begin{array}{r}24540 \\
+11964\end{array}$ & $\begin{array}{r}259745 \\
+4047\end{array}$ & $\begin{array}{r}16784 \\
+11361\end{array}$ \\
\hline & $\begin{array}{l}\text { (2) } \\
\text { Diff. from (3) }\end{array}$ & $\mathrm{Kg}$ & & $\begin{array}{r}210789 \\
-1716\end{array}$ & $\begin{array}{r}20323 \\
-196\end{array}$ & $\begin{array}{r}11008 \\
+910\end{array}$ & $\begin{array}{r}13633 \\
+1057\end{array}$ & $\begin{array}{r}255783 \\
+85\end{array}$ & $\begin{array}{l}6170 \\
+747\end{array}$ \\
\hline & (3) & & & 212505 & 20519 & 10098 & 12576 & 255698 & 5423 \\
\hline \multirow[t]{3}{*}{3.05} & $\begin{array}{l}\text { (1) } \\
\text { Diff. from (3) }\end{array}$ & $\mathrm{Kg}$ & & $\begin{array}{r}161295 \\
+734\end{array}$ & $\begin{array}{r}15171 \\
+31\end{array}$ & $\begin{array}{r}22224 \\
-457\end{array}$ & $\begin{array}{r}17528 \\
-418\end{array}$ & $\begin{array}{r}216218 \\
-110\end{array}$ & $\begin{array}{r}11028 \\
-346\end{array}$ \\
\hline & $\begin{array}{l}\text { (2) } \\
\text { Diff. from (3) }\end{array}$ & $\mathrm{Kg}$ & & $\begin{array}{r}160840 \\
+279\end{array}$ & $\begin{array}{r}15168 \\
+28\end{array}$ & $\begin{array}{r}22522 \\
-159\end{array}$ & $\begin{array}{r}17766 \\
-180\end{array}$ & $\begin{array}{r}216296 \\
-32\end{array}$ & $\begin{array}{r}11252 \\
-122\end{array}$ \\
\hline & (3) & & ' & 160561 & 15140 & 22681 & 17946 & 216328 & 11374 \\
\hline \multirow[t]{3}{*}{4.27} & $\begin{array}{l}\text { (1) } \\
\text { Diff. from (3) }\end{array}$ & $\mathrm{Kg}$ & & $\begin{array}{r}86303 \\
+11407\end{array}$ & $\begin{array}{l}8130 \\
+124\end{array}$ & $\begin{array}{l}11884 \\
-7707\end{array}$ & $\begin{array}{r}9400 \\
-6050\end{array}$ & $\begin{array}{r}115717 \\
-2226\end{array}$ & $\begin{array}{r}5923 \\
-5917\end{array}$ \\
\hline & $\begin{array}{l}\text { (2) } \\
\text { Diff. from (3) }\end{array}$ & $\mathrm{Kg}$ & & $\begin{array}{r}74753 \\
-143\end{array}$ & $\begin{array}{r}7988 \\
-18\end{array}$ & $\begin{array}{r}19662 \\
+71\end{array}$ & $\begin{array}{r}15540 \\
+90\end{array}$ & $\begin{array}{r}117943 \\
+0\end{array}$ & $\begin{array}{r}11902 \\
+62\end{array}$ \\
\hline & (3) & & & 74896 & 8006 & 19591 & 15450 & 117943 & 11840 \\
\hline
\end{tabular}


samples taken from them. The stem was sectioned and weighed piecemeal, and from two to four discs removed depending on tree size.

\section{Laboratory Procedures}

The samples were placed in plastic bags and conveyed to the laboratory where the bark was separated from the stem discs. All specimens were weighed green and then ovendried at $105^{\circ} \mathrm{C}$ until no further weight loss was detected. Wood density was determined for samples taken from the stem discs. Ovendry mass was obtained for each component specimen and its ovendry/green mass ratio determined.

Those ratios were used to calculate the OM of each tree, by its main components. Stem wood density was calculated from results found with the disc samples.

A height/dbh curve was prepared from the sample trees for each associated plot, and a height assigned to every tree on it. The equations developed below were used to estimate OM values for every tree, and OM per hectare was compiled for each plot by summation.

\section{Analysis}

Stepwise regression analysis was applied to the wholetree and component mass data, first using a combined form of the basic tree variables of $\mathrm{dbh}$ and height, then assessing the additional contribution of spacing (expressed as equivalent numbers of trees per hectare) and finally that of age, as follows:

$$
\begin{aligned}
& O M=b_{0}+b_{1} \bullet\left(d^{2} \bullet h\right) \\
& O M=b_{0}+b_{1} \bullet\left(d^{2} \bullet h\right)+b_{2} \bullet 1 / n \\
& O M=b_{0}+b_{1} \bullet\left(d^{2} \bullet h\right)+b_{2} \bullet 1 / n+b_{3} \bullet t
\end{aligned}
$$

where $\mathrm{OM}=$ oven-dry mass of component or whole tree in kilograms

$\mathrm{d}=\mathrm{dbh}(\mathrm{ob})$ in centimetres

$\mathrm{h}=$ height in metres

$n=$ number of trees/ha at time of planting

$\mathrm{t}=$ age from planting in years

OM values for dead branches were calculated independently and not included in whole tree totals, which represent living material only in accordance with FordRobertson's (1971) definition of biomass.

\section{Results and Discussion}

\section{Regression Models}

Table 2 presents the coefficients and statistics for the three regression models. It is evident that the addition of spacing and age shows successive improvements in the estimates over those provided by $\mathrm{d}^{2} \mathrm{~h}$ alone. It is also evident that these improvements are minimal for the whole tree and for stem bark.

By contrast, markedly better statistics result for stem wood, branches and for twigs plus needles when spacing and age are introduced, with Model 3 giving the best estimates. The same applies to dead branches, which gave the least satisfactory results. It is not believed that branch and foliage estimates could be improved without introducing measurements of crown dimensions, which is not feasible in normat-inventory work.

Owing to the superior performance of Model 3, it is used as the standard in the following discussion.

\section{Magnitude of Errors from Model 1 and 2 Estimates}

The potential for error in per hectare estimates derived from other than Model 3 is indicated in Table 3 , for the means of three spacing classes. As would be expected from the comparative $R^{2}$ values shown in Table 2 , the magnitude of differences is least for bark and for the whole tree. For other components, differences from Model 3 estimates can be considerable, varying in amount and sign with spacing. Model 1 gives values as high as $14701 \mathrm{~kg} / \mathrm{ha}$ and $145 \%$ greater than those for Model 3 estimates of live branches at close spacings, but $7707 \mathrm{~kg} / \mathrm{ha}$ and $39.3 \%$ less at wide spacings. On the other hand Model 1 estimates for stem wood are underestimated at the closer spacing, overestimated at the wider spacing. Values derived with Model 2 differ numerically much less from those of Model 3 , and show a maximum $9 \%$ difference. Subsequent tables herein show only Model 3 estimates.

\section{Spacing Effects}

The general spacing effects on OM are illustrated in Table 4 with a series of five plantations of the same age but planted at different spacings. Lower total biomass is clearly associated with wider spacing, and the same is true for the OM of all components except live branches. The proportions of stem wood and stem bark also decline with greater spacing, while the proportion of live branches increases and that of twigs plus needles shows an upward trend only at the widest spacing. These results receive some support from similar findings with balsam fir (Abies balsamea [L.] Mill) by Baskerville (1965).

\section{Age Effects}

An example of age effects is shown in Table 5 by three plantations of different ages but all established at the same spacing. Here total biomass increased with age, as does the $\mathrm{OM}$ of stem wood and bark. OM of twigs plus needles decreases with age, but that of live branches shows no clear trend. Proportion of stem wood OM increases with age, that of live branches and of twigs plus needles decreases; bark shows little change.

Thus, for comparable sites, the greatest amount of biomass (321 $365 \mathrm{~kg} / \mathrm{ha})$ found on any plot was contained in the oldest (54 years) and most closely planted (1.52-m) plantation. Inis total OM included $9680 \mathrm{~kg}$ of live branches, $8349 \mathrm{~kg}$ of twigs plus needles, as well as $1345 \mathrm{~kg}$ of dead branches, for a total of $19374 \mathrm{~kg} / \mathrm{ha}$ in non-stem material

\section{Percentage Stand Estimates}

These trends can be consolidated into a regression of the form:

$\mathrm{P}=\mathrm{b}_{0}+\mathrm{b}_{1} \cdot 1 / \sqrt{\mathrm{n}}+\mathrm{b}_{2} \cdot 1 / \mathrm{t}+\mathrm{b}_{3} \cdot 1 / \mathrm{t} \sqrt{\mathrm{n}}$

where $\mathrm{P}=$ percentage of whole-tree $\mathrm{OM}$ contained in a particular component on a stand basis. Table 6 indicates the coefficients and statistics, by tree component. The actual proportions of the live part of the tree, by components, necessarily total $100 \%$. Since the equation for each live component was derived independently, using the same variables, then the estimated proportions for the live components add up to $100 \%$; dead branches are estimated separately. Figure 1. illustrates variation with spacing of component percentages for three selected ages, (a) to (d); (e) represents the residues likely remaining after conventional logging (unmerchantable top excepted). Similarly, regression Model 4 can be used to estimate whole-tree and component OM's as percentages of stem wood which may 

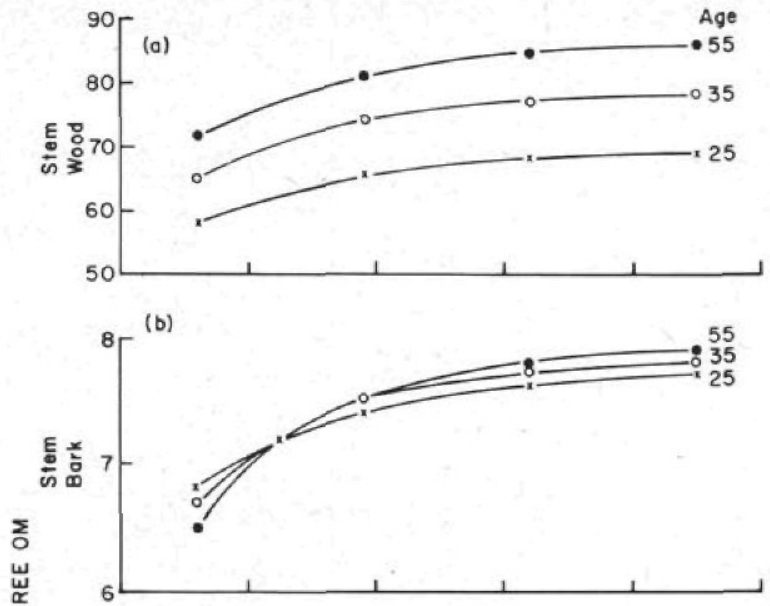

(c)

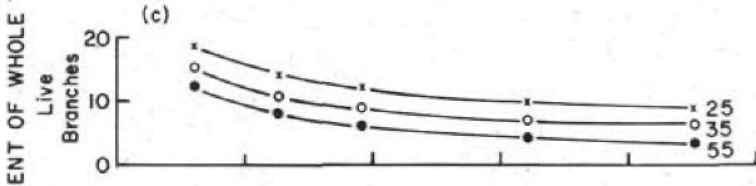

(d)
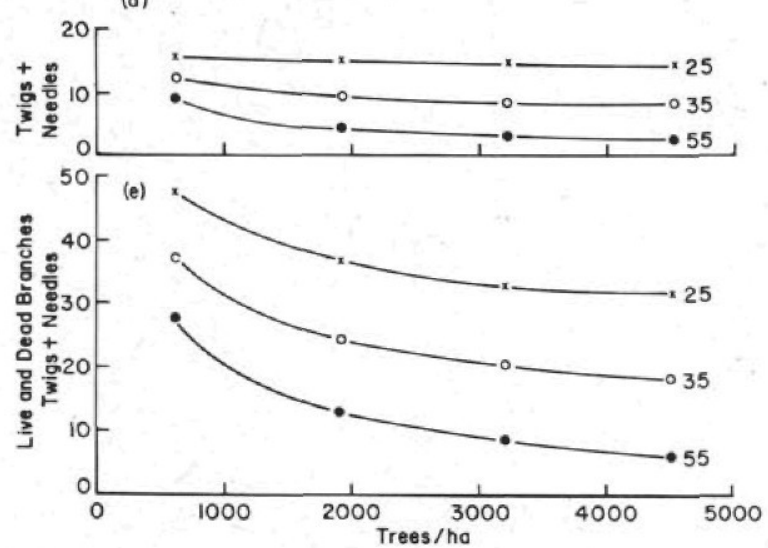

Figure 1. Variation of percentage component mass with age and spacing.

be the only mass value available; the relevant coefficients are shown in Table 7

\section{Basic Wood Density}

The 608 stem wood specimens taken from the 155 sam. ple trees gave an average basic wood density (ovendry mass to green volume) of $0.364 \mathrm{~g} / \mathrm{cm}^{3}$, equivalent to 364 $\mathrm{kg} / \mathrm{m}^{3}$. In situations where no stem measurement data are available, but total or merchantable volume in cubic metres, either per tree or per hectare, is known, stem wood OM in kilograms can be approximated by multiplying the particular volume by 364 .

\section{Additivity of Component Estimates}

A property of the single-tree mass equations developed here is their additivity. As pointed out by Alemdag (1981), with equations of this type the result obtained with the whole-tree regression is identical to that found by summing the estimates obtained for the components by solving their individual regressions. In obtaining stand estimates (for the whole tree or any component) it is not necessary to solve the equations for every tree, but rather they can be applied to the mean $\mathrm{dbh}$ and height of each diameter class, multiplied by class frequency and the results summed. Or, equations can be solved for stand mean height and diameter, and multiplied by the number of trees per hectare now present (Alemdag and Horton 1981). Results of this procedure when applied to the plantation data used in the study did not differ from per hectare estimates based on single tree values for any plot by more than $0.49 \%$.

\section{Sampling Requirements for Model 3}

Obtaining inputs for Model 3 equation should pose no problems, but it must be borne in mind that the regression is only applicable to unthinned, reasonably high-survival plantations where mortality has been mostly caused by natural competition and suppression and not appreciably by external causes. Dbh and height data are collected routinely. The number of trees (n) at the time of planting is found by measuring the distance between rows and between trees and includes evident gaps caused by failure at any stage. The average of these distances is the average initial spacing $(\mathrm{S})$, and trees/ha $(n)=10000 /(\mathrm{S} \text { in } \mathrm{m})^{2}$. Age of plantations is nearly always recorded, but if not then counting internodes is a simple procedure with red pine.

In this study the plantations were established on a variety of soil conditions. It is considered that the use of both height and age in the regression model adequately compensates for any site-induced growth differences.

\section{Behaviour of Stand Biomass}

The occurrence of greater mass per hectare of twigs plus needles at closer spacings agrees with findings for foliage OM estimated from crown dimerisions in some of these stands (Stiell and Berry 1977).

\begin{tabular}{|c|c|c|c|c|c|c|c|c|}
\hline \multirow[b]{2}{*}{$\begin{array}{l}\text { Spacing } \\
\text { (m) }\end{array}$} & \multirow[b]{2}{*}{$\begin{array}{l}\text { Mean h } \\
\text { (m) }\end{array}$} & \multicolumn{7}{|c|}{ Ovendry mass per hectare } \\
\hline & & OM & $\begin{array}{l}\text { Stem } \\
\text { wood }\end{array}$ & $\begin{array}{r}\text { Stem } \\
\text { bark }\end{array}$ & $\begin{array}{c}\text { Live } \\
\text { branches }\end{array}$ & $\begin{array}{c}\text { Twigs }+ \\
\text { needles }\end{array}$ & $\begin{array}{c}\text { Total } \\
\text { biomass }\end{array}$ & $\begin{array}{c}\text { Dead } \\
\text { branches }\end{array}$ \\
\hline 1.52 & 14.4 & $\begin{array}{l}\mathrm{Kg} \\
\%\end{array}$ & $\begin{array}{r}136788 \\
71.8\end{array}$ & $\begin{array}{r}15126 \\
7.9\end{array}$ & $\begin{array}{r}13883 \\
7.3\end{array}$ & $\begin{array}{r}24805 \\
13.0\end{array}$ & $\begin{array}{r}190602 \\
100.0\end{array}$ & $\begin{array}{r}15392 \\
8.1\end{array}$ \\
\hline 1.83 & 14.1 & $\begin{array}{l}\mathrm{Kg} \\
\%\end{array}$ & $\begin{array}{r}119210 \\
69.4\end{array}$ & $\begin{array}{r}13192 \\
7.7\end{array}$ & $\begin{array}{r}16322 \\
9.5\end{array}$ & $\begin{array}{r}22979 \\
\quad 13.4\end{array}$ & $\begin{array}{r}171705 \\
100.0\end{array}$ & $\begin{array}{r}15072 \\
8.8\end{array}$ \\
\hline 2.13 & 15.1 & $\begin{array}{l}\mathrm{Kg} \\
\%\end{array}$ & $\begin{array}{r}115644 \\
69.2\end{array}$ & $\begin{array}{r}12136 \\
7.3\end{array}$ & $\begin{array}{r}18454 \\
11.0\end{array}$ & $\begin{array}{r}20951 \\
12.5\end{array}$ & $\begin{array}{r}167185 \\
100.0\end{array}$ & $\begin{array}{r}13894 \\
8.3\end{array}$ \\
\hline 3.05 & 14.3 & $\begin{array}{l}\mathrm{Kg} \\
\%\end{array}$ & $\begin{array}{r}82808 \\
65.0\end{array}$ & $\begin{array}{r}8815 \\
6.9\end{array}$ & $\begin{array}{r}18675 \\
14.7\end{array}$ & $\begin{array}{r}17130 \\
13.4\end{array}$ & $\begin{array}{r}127428 \\
100.0\end{array}$ & $\begin{array}{r}12388 \\
9.7\end{array}$ \\
\hline 4.27 & 13.7 & $\begin{array}{l}\mathrm{Kg} \\
\%\end{array}$ & $\begin{array}{r}54073 \\
58.3\end{array}$ & $\begin{array}{r}6251 \\
6.7\end{array}$ & $\begin{array}{r}17869 \\
19.3\end{array}$ & $\begin{array}{r}14590 \\
15.7\end{array}$ & $\begin{array}{r}92783 \\
100.0\end{array}$ & $\begin{array}{r}11583 \\
12.5\end{array}$ \\
\hline
\end{tabular}


Table 5. Age effects on amount and proportion of components - - spacing $2.13 \mathrm{~m}$ (Model 3).

\begin{tabular}{|c|c|c|c|c|c|c|c|c|}
\hline \multirow[b]{2}{*}{$\begin{array}{c}\text { Age } \\
\text { (years) }\end{array}$} & \multirow[b]{2}{*}{$\begin{array}{c}\text { Mean h } \\
(\mathrm{m})\end{array}$} & \multicolumn{2}{|r|}{. } & \multicolumn{3}{|c|}{ Ovendry mass per hectare } & \multicolumn{2}{|l|}{+} \\
\hline & & OM & $\begin{array}{l}\text { Stem } \\
\text { wood }\end{array}$ & $\begin{array}{r}\text { Stem } \\
\text { bark }\end{array}$ & $\begin{array}{c}\text { Live } \\
\text { branches }\end{array}$ & $\begin{array}{c}\text { Twigs }+ \\
\text { needles }\end{array}$ & $\begin{array}{c}\text { Total } \\
\text { biomass }\end{array}$ & $\begin{array}{c}\text { Dead } \\
\text { branches }\end{array}$ \\
\hline 27 & 15.1 & $\begin{array}{l}\mathrm{Kg} \\
\%\end{array}$ & $\begin{array}{r}115644 \\
69.2\end{array}$ & $\begin{array}{r}12136 \\
7.3\end{array}$ & $\begin{array}{r}18454 \\
11.0\end{array}$ & $\begin{array}{r}20951 \\
12.5\end{array}$ & $\begin{array}{r}167185 \\
100.0\end{array}$ & $\begin{array}{r}13894 \\
8.3\end{array}$ \\
\hline 39 & 16.6 & $\begin{array}{l}\mathrm{Kg} \\
\%\end{array}$ & $\begin{array}{r}150904 \\
76.7\end{array}$ & $\begin{array}{r}15510 \\
7.9\end{array}$ & $\begin{array}{r}14777 \\
7.5\end{array}$ & $\begin{array}{r}15648 \\
7.9\end{array}$ & $\begin{array}{r}196.839 \\
100.0\end{array}$ & $\begin{array}{r}9878 \\
5.0\end{array}$ \\
\hline 53 & 23.7 & $\begin{array}{l}\mathrm{Kg} \\
\%\end{array}$ & $\begin{array}{r}243442 \\
81.3\end{array}$ & $\begin{array}{r}22344 \\
7.5\end{array}$ & $\begin{array}{r}19011 \\
6.3\end{array}$ & $\begin{array}{r}14571 \\
4.9\end{array}$ & $\begin{array}{r}299368 \\
100.0\end{array}$ & $\begin{array}{r}6834 \\
2.3\end{array}$ \\
\hline
\end{tabular}

Table 6. Regression coefficients for estimating percentages of whole tree ovendry mass by components on a stand basis (Model 4).

\begin{tabular}{|c|c|c|c|c|c|c|}
\hline Component & $b_{0}$ & $b_{1}$ & $b_{2}$ & $\mathbf{b}_{3}$ & $\mathbf{R}^{2}$ & SEE $\%$ \\
\hline Stem wood & 109.74786 & -645.68619 & -851.69454 & 5311.99072 & 0.990 & 1.21 \\
\hline Stem bark & 9.21374 & -72.44949 & -24.68094 & 949.86918 & 0.809 & 3.30 \\
\hline Live branches & -6.03320 & 322.28289 & 221.04867 & 2058.79579 & 0.981 & 3.37 \\
\hline Twigs + needles & -12.92840 & 395.85279 & 655.32681 & -8320.65569 & 0.988 & 2.86 \\
\hline (Dead branches) & -10.81632 & 270.26166 & 446.50139 & -3310.83163 & 0.990 & 3.05 \\
\hline
\end{tabular}

Table 7. Regression coefficients for estimating percentages of stem wood ovendry mass by components and whole tree on a stand basis (Model 4).

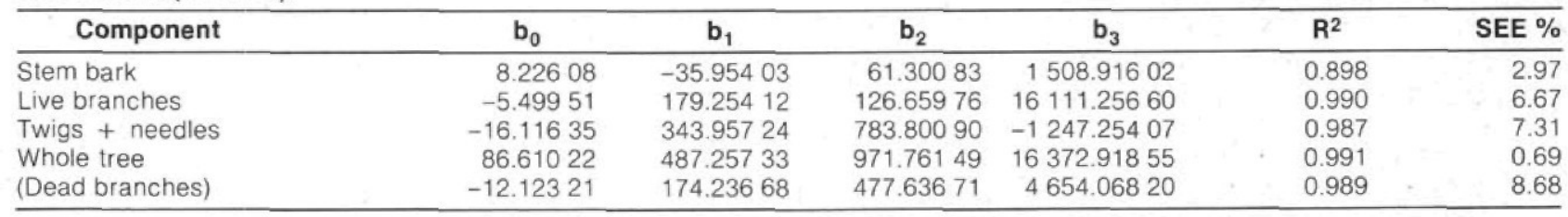

Behaviour of mass per hectare of the whole tree, and of stem wood and bark as well, was similar to that found for stand volume, i.e. all increased with closer spacing and greater age. Greater stand biomass accompanying closer spacing has been reported elsewhere for red pine in plantations where density was not so great as to reduce height growth (Heiberg et al. 1959, Maeglin 1967), but in one threespacing trial biomass per hectare maximized in the middle spacing class (Singer and Hutnik 1966).

\section{Conclusions}

1. Single-tree equations for plantation red pine, based simply on $\mathrm{dbh}$ and height, would give satisfactory ovendry mass estimates only for the whole tree and for the component stem bark.

2. Acceptable independent mass estimates of stem wood, live branches, twigs plus needles and of dead branches require the introduction into the equation of initial spacing (expressed as trees/ha) and preferably of age as well.

3. If red pine were to be grown as energy plantations, greatest biomass production at a given age would be attained at close spacings (1.52 $\times 1.52 \mathrm{~m}$ or less), and at greater ages (at least to 54 years) for a given spacing.

4. In a thinning or harvesting operation for conventional products, residues available for fuel would include (depending on plantation spacing and age) from 2 to $19 \%$ in the live branches and 2 to $16 \%$ in twigs plus needles, with an additional 0.2 to $13 \%$ in dead branches, for a maximum of $48 \%$ of the total biomass removed.

\section{Acknowledgements}

C.F. Robinson supervised the field and laboratory work for this study and provided the basic data. D.A. MacLeod advised on statistical methods and T.L. Pickett was responsible for the computer analysis, D.J. McGuire drafted Figure 1.

\section{References}

Alemdag, I.S. 1980. Manual of data collection and processing for the development of forest biomass relationships. Dep. Environ., Can. For. Serv., Chalk River, Ont. Inf. Rep. PI-X-4. 38p.

Alemdag, I.S. 1981. Aboveground-mass equations for six hardwood species from natural stands of the research forest at Petawawa. Dep. Environ., Can. For. Serv., Chalk River, Ont. Inf. Rep. PI-X-6. 9 p.

Alemdag, I.S. and K.W. Horton. 1981. Single-tree equations for estimating biomass of trembling aspen, largetooth aspen and white birch in Ontario. For. Chron. 57(4): 169-173.

Baskerville, G.L. 1965. Dry-matter production in immature balsam fir stands. For. Sci. Monograph 9. $42 \mathrm{p}$.

Berry, A.B. 1977. Metric yield tables based on site class and spacing for unthinned red pine plantations at the Petawawa Forest Experiment Station. Dep. Environ., Can. For. Serv. Chalk River, Ont. Inf. Rep. PS-X-65. 17 p.

Brown, James K. 1963. Crown weights in red pine plantations. US Dep. Agric., For. Serv., Lake States For. Exp. Stn. Res. Note LS-19, 4 p.

Ford-Robertson, F.C., Ed. 1971. Terminology of forest science, technology, practice and products. English-language version. Soc. Am. For., Washington, DC. 349 p.

Frederick, Douglas J. and Michael S. Coffman. 1978. Red pine plantation biomass exceeds sugar maple on northern hardwood sites. J. For. 76(1):13-15.

Hannah, Peter R. 1969. Stemwood production related to soils in Michigan red pine plantations. For. Sci. 15(3): 320-326.

Heiberg, S.O., L. Leyton and H. Loewenstein. 1959. Influence of potassium fertilizer level on red pine planted at various spacings on a potassium-deficient site. For. Sci. 5(2): 142-153.

Maeglin, Robert F. 1967. Effect of tree spacing on weight yields for red pine and jack pine. J. For. 65(9): 647-650.

Singer, Frank P. and R.J. Hutnik. 1966. Accumulation of organic matter in red pine and Norway spruce plantations of various spacings. Penn. State Univ., School For. Resour. Res. Briefs 1(1): $22-27$

Stiell, W.M. and A.B. Berry. 1977. A 20 -year trial of red pine planted at seven spacings. Dep. Environ., Can. For. Serv., Ottawa, Ont. Inf. Rep. FMR-X-97. 25 p. 